\title{
A theological perspective on migrants and migration focussing on the Southern African Development Community (SADC)
}

\section{Nico A Botha ${ }^{1}$}

\begin{abstract}
The main purpose of the paper is to draw some contours of a theology of migration. The specific focus in the paper is on the Southern African Development Community (SADC) which constitutes a very complex situation of human migration from neighbouring countries to South Africa. The praxis cycle is called into service to construct a theology of migration informed by insertion, context analysis, theological reflection and strategic planning. The main thesis of the paper is that a theology of migration should as a bare minimum reflect the following dimensions: a theological theology, i.e. the language about God in the context of migration, a narrative theology, a liturgical-communal theology and an intercultural and interreligious theology. The proposal offered on strategic planning is aimed at the radical transformation of relationships between South Africans and migrants.
\end{abstract}

"Nothing that we produce as Theology will reach the migrant's hands in his/her journey to cross the border” (Juan Luis Loza Léon)

\section{Introduction}

The main objective of the article is to draw the contours of a theology of migrants and migration. Theology and the church can no longer turn a blind eye to the challenges the continuous movement of people across borders in the Southern African Development Community or SADC region pose. Rough estimates are that there are currently about two million documented and undocumented Zimbabweans in South Africa. Worldwide there are something to the tune of two hundred million migrants. This paper is, however, confined to the situation in the SADC region with the view of showing what a theology or Missiology of migrants and migration may look like. The pastoral or praxis cycle is called into service for developing some contours of such a theology. From the start the following underlying assumption on the kind of theology this paper wishes to advance, needs to be declared: going beyond a mere grasp of the situation to fundamental change. In the context of the article therefore, the development of a theology of migrants and migration is not aimed at harmonising the situation or containing it, but it is geared towards transformation. The article speaks to the need to work towards radical change in the relationship

1 Nico Botha is professor of Missiology in the Department of Church History, Christian Spirituality and Missiology at the University of South Africa. He can be contacted at bothana@unisa.ac.za 
between South Africans and migrants from neighbouring countries. This need has nowhere else been exposed more violently than in the tragic outbreak of xenophobia in South Africa in May 2008.

The praxis cycle as it originated with Holland and Henriot (1983) is a four-step cycle of insertion, context analysis, theological reflection and planning. By introducing the cycle I am suggesting that at least the following contours should be part of a Missiology of migrants and migrations, namely a clear insertion into or identification with the context of migrants, an understanding of the context, and a reading of the Bible in context and relevant strategic planning aimed at the transformation of relationships.

\section{Organisation}

Informed by the brief introduction with particular reference to the use of the praxis cycle, the article is organised as follows. First, the cycle's step on insertion is introduced. A brief look is taken at different levels of migration and the options to be exercised and choices to be made in a commitment to migrants. Second, a provisional context analysis is offered based on a common sense reading of the situation and some literature on migration in the SADC region. Third, the theological reflection deals with the question of what language to use about God in the context of migration. The argument is advanced that a theology of migrants and migration will reflect different dimensions. Fourth, in tapping into the notion of "konvivenz", issues around which some strategic planning could be done, are shown.

\section{Insertion}

At no time in the history of South Africa has the need to investigate the issue of migration been felt so acutely than since the horrific xenophobia attacks of May 2008 where some migrants were killed and others maimed. In the unit for Missiology at the University of South Africa there was a decision to look into the question of xenophobia by embarking upon a serious research project. Around 2009 a contract appointment was made of someone earmarked for research into the matter. The collaborative research project on human migration in Missiology is intentionally or unintentionally a follow-up on the issue. Incidentally during the exact time of the reworking and updating of this article for publication, new trouble has erupted in an area called Diepsloot, in the vicinity of Centurion, south of Pretoria -Tshwane where mainly young people and children have been looting shops belonging to migrants mainly from Somalia and Zimbabwe. This was preceded by a shooting incident in which a migrant from Somalia killed two Zimbabweans who have allegedly tried to loot his shop. In a very real sense this is black on black violence which triggers the question whether this could still be called xenophobia or rather Afrophobia as suggested by 
Tshaka (2010:91-111). Much as Tshaka's speculation on whether this is not a result of an underlying self-hatred, the term Afrophobia obscures the fact that perpetrators as well as victims are Africans. A further issue is that the notion can quite easily also conceal the whole complex of underlying issues, for example the political and socio-economic mechanisms of which both perpetrators and victims bear the brunt.

For staff members in the unit for Missiology at Unisa and of course for Unisa people across the sections and departments, the encounter with foreigners is a daily experience. With the strong emphasis in Missiology on postgraduate students supervisors in the unit cannot avoid the encounter with candidates from the Democratic Republic of the Congo, Kenya and Nigeria, to mention these three only. These are Masters and Doctoral students who choose to stay in South Africa for periods of time or even for the duration of their studies.

On a different level, through its project on community engagement, the Missiology unit encounters internal homeless migrants in the city of Pretoria-Tshwane. These are South Africans who land on the streets of the city through circumstances beyond their control most of the time. They migrate from rural or other bigger towns in search of employment or something to survive on. In some instances they go by foot for tens of kilometres from one town to another. Serious research into their precarious situation will reveal anecdotes and stories emanating from their experiences.

On yet another level, migrants from neighbouring countries are encountered on a daily basis right in the communities where people live. A case in point is the township of Eersterust in Pretoria-Tshwane that has been transformed into a "little Zimbabwe" in terms of the number of Zimbabwean migrants, documented or undocumented- in particular women who come there to work as domestic helps. Some have found some form of residence in Eersterust. In prolonging the discussion on insertion somewhat, let us now turn to the element of choice as essentially the most important aspect of insertion. In the understanding of Holland and Henriot (1980, 1983), insertion refers typically to the choices we make and the values we espouse. They reduce this then to the preferential option for the poor. In the context of the article the option is extended to migrants, most of whom worldwide and in particular in the SADC region are in a desperate situation taking on diverse forms like poverty, unemployment, risk of life, risk of incarceration, hunger, disease and numerous other related issues. In the movement of people across borders between Zimbabwe and South Africa, for example, it can be observed that quite a number of migrants are unaccompanied children whose parents have either died or deserted them. 


\section{Context analysis}

In terms of the logical coherence of the praxis cycle some measure of context or social analysis is as indispensable as insertion. The praxis cycle debunks any notion of a theology which draws a straight line between the text of the Bible and the context we live in. Put differently, the use of the praxis cycle as a theological method, reveals wariness of theological constructs which feed into the assumption that good theology is a good application of the text of the Bible to any given situation. The praxis cycle challenges theology to gravitate from a linear reading of the Bible to a mediated understanding of the text. One such mediation is context or social analysis.

For the construction of a theology of migration in the SADC region, context analysis is very necessary. In the literature on migration in the SADC region the issue is located squarely in the SADC objectives. In August 1992 when the former Southern African Development Coordination Conference (SADCC) was transformed into SADC, the objectives spelt out centred on development and economic growth, poverty alleviation, common political values, systems and institutions, historical, social and cultural affinities and self-reliance (Williams 2002). Implicitly one could argue that these objectives were formulated in response to a situation of underdevelopment, poverty, want, slow economic growth, lack of collaboration in key areas and political instability. What has emerged in SADC as a key issue is the free movement of people across borders between the SADC countries. There appears to an ambivalence between the protocol on the free movement of people which was drafted by consultants in 1995 and the negative reactions of some states like Botswana, Namibia and South Africa to the protocol (Williams 2002; Schachter 2009).

In his study titled Data Assessment of Labour Migration Statistics in the SADC Region: South Africa, Zambia, Zimbabwe on behalf of the International Organization for Migration (IOM), Schachter (2009) highlights important contextual factors on migration. One of his major findings is the technical weakness relating to the collection and measurement of migration data with specific reference to matters like poverty, labour and health. Further issues coming to the fore in the study are the weak economic conditions in the region, conflicts in diverse forms and in particular the quest amongst refugees for political and economic stability. Reference is also made to the cross border trading that is taking place and the way in which undocumented migrants exploit the porous borders between countries.

As far as real existing power relationships are concerned the study exposes the protectionism of countries with a stronger economy like Botswana, Namibia and South Africa. There is a serious issue also as far as 
the stereotyping of migrants as social, economic and criminal threats are concerned.

There is a real need for deeper and thoroughgoing analysis. However, the brief conversation indicates a number of sources which cannot be avoided in the search for a better understanding of issues informing migration in the SADC region. The analysis will have to speak to a variety of prevailing social, political, economic and cultural realities. In terms of specifics as far as this is concerned the issues already identified as paramount are poverty and poverty alleviation, development, labour, health, education and regional stability.

\section{Theological Reflection}

\section{The hermeneutic of "stranger"}

The theological reflection in this article is to be mediated by the hermeneutic of "stranger". Some measure of theological justification for using the term is to be found in the text of the Bible and in the Confession of Belhar (1986) where the "stranger" is grouped together with categories of human beings like the needy, the poor, widows and orphans. The Confession of Belhar projects an image of God as the God who is in a special way on the side of these categories of people. In the context of this article "stranger" does not only refer to migrants from another country or region, but also internal migrants. Perhaps there is a need to indicate just briefly something of the origin of the Confession of Belhar. Adopted in 1986 as a confession of the former Dutch Reformed Mission Church, it is a theological response to the heresy of apartheid as far as the moral and theological justification of the system is concerned. The main themes of the confession are unity, reconciliation, justice and obedience. Since April 1994 with the unification of the Dutch Refomed Mission Church and the Dutch Reformed Church in Africa, the Confession of Belhar forms part of the body of confessions of the newly established Uniting Reformed Church in Southern Africa.

Before introducing Sundermeier's concept of "konvivenz", it needs to be mentioned that the literature, scant as it is at this point in time, already shows a diversity of theologies of migration. The ones that will be shown here are a theological theology of migration, a theology of migration as a narrative theology, a liturgical-communal theology and an intercultural and interreligious theology.

\section{Sundermeier on "konvivenz"}

In the discipline of Missiology the concept of "stranger" was introduced in a serious manner by Sundermeier (1995) in his notion of "konvivenz". He contends that in the encounter between us and the stranger, or let us say the Christian us or the missiological us and the stranger, goes beyond 
communication and an incidental encounter. In introducing the concept of "konvivenz" which origins are difficult to trace, except knowing that there are some roots in the Latin American base communities, Sundermeier understands it to be the seeking of lasting and spacial connections. He then goes on to unpack the concept further in terms of the triad of a caring, learning and celebrating community. Later in the article the triad is to be explored further for its potential to facilitate strategic planning in the search for transformed relationships in the encounter between South Africans and migrants.

\section{A theological theology}

What is offered here as an article had been done as a powerpoint presentation initially at the Joint Conference of academic societies in religion and theology at the University of Kwazulu-Natal in Pietermaritzburg in June 2012. During discussion time, some participants raised important questions relating to culture and religion or faith in the context of migration. Mangayi (2012) drew attention to the culture migrants bring and Landman (2012) challenged the silence in the presentation on the faith or religion of the migrants. I shall return to the issue of culture later, but for now a response to the issues on faith or belief or religion raised by Landman calls for a comment or two. Yes, indeed most migrants from the SADC region would have an understanding of faith or religion either in terms of being Christian or Muslim or adherents to the African Traditional Religion (ATR). The issue constitutes an important area of research informed by Landman's question on the faith or religion migrants bring. In a speculative manner the assumption that migrants quite often survive and even more than survive, because of the sustenance drawn from their faith, may not be too far-fetched.

\section{The theological nature of a perspective on migration}

A missiological perspective on migration should by definition be theological. A Missiology of migration is a theological Missiology. This simply means that in the context of human migration which most of the time is the story of gross human dislocation, a few pertinent questions need to be asked about our God-talk, our language of God or simply the words we use in describing God. At issue here is the simple, but pertinent question posed by Loza Léon (2008:25): "which is the proper way of speaking about God when addressing migrants?” In an ironic fashion of course, he does not attempt at all to answer the question in academic terms, but responds with poetry as music as a manner of communicating with migrants in their condition: "Let the walls be taken...let the borders be open". 


\section{God as a migrant, God the refugee}

Attempts of emerging proponents on a theology of migration at metaphorically describing God as a migrant God or a refugee God go a long way in locating the language about God in the context of migration. In order to avoid such depictions of God to serve as lullabies for poor, dislocated, struggling migrants, a dialectical interpretation is necessary. In many different senses the God of the Bible is a migrant God. This is first and foremost born out in his migration from a non-accessible light to creation. In Christ Jesus He became incarnated, pitching his tent in the neighbourhood. A Christological perspective on migrants and migration is indispensable for a creative dialectical theological-missiological understanding of migration. In his brief, but incisive article, Askevold (2008:47-49) portrays Jesus as a "wandering Aramean", arguing that all human beings are sons and daughters of the Aramean. In telling the story of the flight of Joseph, Mary and Jesus by showing how Jesus himself had to flee from persecution, he provides us with a handle on a dialectical analysis: "Every migrant", says Askevold, "carries the face of Christ, and this compels us to act in a way that protects this innate dignity" (:49). On the one hand a Christological perspective on migration reveals how Christ identifies with migrants, having been one himself, not as an economic migrant, but as a refugee. On the other hand the identification de-stigmatises migrants and affirms them in their dignity. In a similar vein, Saman (2008:53-59) depicts Jesus Christ as an asylum seeker, refugee and migrant. In a fascinating way he introduces what could be seen as a marvellous piece of narrative theology the way he describes, analyses and interprets the migration story at the very beginning of the New Testament. He points out that Jesus was not merely a migrant, but an alien who "came from heaven (the outer limits of space - although he did tell us the kingdom is within) and took the form of a human being to become for us the Refugee Christ” (:53). Central to the unfolding migration story of Jesus Christ is the notion from Luke 9:58 that "the foxes have holes and the birds of the air have nests, but the Son of Man has nowhere to lay His head". Once again the dialectic here is that of awkwardness, of being destitute on the one hand, but the paradoxical truth is that this very refugee brings salvation.

\section{Where is God in migration?}

A theological Missiology is a tautological way of speaking. Why then is such a construction necessary? At the Joint Conference, alluded to earlier where Landman posed the pertinent question about the faith, religion or belief of the migrants themselves, her question actually went much deeper than the standard academic question of what kind of religion do migrants adhere to? If she was understood correctly, the question was rather whether the neat, rational academic constructs we produce and which we call "theology of migration", really speaks to the very complex issue of 
migration with its danger, fear, despair, persecution, disease, suffering and death? Of course not and precisely for that reason there is a need for a theological Missiology. Where is God in migration? Where and who is Jesus Christ in migration? The answer is God Himself is a refugee and a migrant, Jesus Himself is a refugee, an alien, a migrant and an asylum seeker.

\section{Groody}

None other has enriched the quest for a theological missiological perspective on migration more than Groody (2005, 2008, 2009, 2011a and 2011b). The brief discussion here focuses on his very creative use of the concepts imago Dei, verbum Dei, missio Dei and visio Dei. The basic genius of calling these concepts into service is that they contribute substantially to the "bridging" of the "migration-theology" divide. If he is understood correctly Groody suggests that the lack of theological reflection and writing on human migration results from the divides operating between migration and theology in itself and further between problem and person, the divine and the human, and between human and human. Groody constructs a deep answer to the matter by engaging human migration from the perspective of God's image in all people, God's Word for all people and God's universal mission. In calling into service the metaphor of the visio Dei based on Matthew 5:8, "Blessed are the pure in heart for they shall see God", he argues that this can potentially assist in crossing the country-kingdom divide. The remarkable theological contribution of Groody in the context of migration is that he succeeds in creatively subverting rather painful realities of suffering, despair, hunger and death to speak of God in new ways: God becomes the one who crosses borders and overcomes barriers and brings people into reconciliation with Him through Christ and with one another.

\section{A Narrative theology}

\section{The Bible as a book of stories}

The need for a theology or Missiology of migration has amongst others triggered the rediscovery of the Bible as a book of stories. One of the major narrative trajectories in the Bible is the story of migration. In a very rich manner this trajectory unfolds in Askevold's (2008:47-49) brief article titled We are all sons and daughters of a wandering Aramean and Saman's (2008:53-59) piece titled Jesus Christ: Asylum Seeker, Refugee and a Migrant, already referred to in this article. Of note in the Biblical stories on migration are the Abraham narrative, the exodus from Egypt and the story of the "Holy Family". There are many more to add in terms of Bible characters facing migration, such as the narrative of the Babylonian captivity in terms of both the exile and the liberation from exile of the 
people of Israel. A very creative perspective on migration would be the identification in the New Testament of Christians, the disciples of Jesus Christ as people of the Way or as paroikia or strangers or aliens in the letters of Peter, for example. There is a constant trajectory of the church as being underway, as gravitating to a new land, as being on a quest for a new city as in Hebrews 13:14. It is the story of a remarkable journey with its numerous challenges and setbacks on the one hand and here and there the unfolding of the most exciting adventures and of stumbling upon unseen territories.

\section{Story as the starting point}

The story of Groody's (2011) conversion to migration alluded to previously, makes it clear that the starting point of a theology of migration is story. It was not the big theological constructs, nor a razor sharp analysis, but seeing the migrant from the comfort of a student apartment in California that has brought about the conversion to the stranger. In the connection between the story of the desperate migrant, Groody's own story of transformation and the Biblical trajectory of migration, a creatively new theological discourse on human migration is borne. In Groody's own narration:

As a graduate student in theology, I lived in a large university town near San Francisco. My room was in the basement of the house, where I spent many hours studying some of the best thinkers in the Christian tradition. After getting up one morning, I looked out my window. On the other side of the wall from where I had slept was a homeless man. Physically we were little more than a foot-and-half away from each other. Existentially, however, we lived in two different worlds. My reality was a comfortable home, a warm bed and a life of the mind; his was distress and discomfort, a brick mattress and a life of the streets. That experience changed not only the way I thought about theology but also the way I began to do it. ${ }^{2}$ Groody's story contains some metaphors which are crucially important in the conversion to migrants. Metaphorically and in real terms we are quite often separated from migrants by a wall of partition. It is only when we change our gaze by looking beyond the wall that we shall observe the discomforted, distressed, homeless migrant. The conversion required in the encounter with migrants is a deep metanoia which entails a radical gravitation from one world to another.

In the SADC region on which the focus is in the article there would be numerous stories from migrants on the motivation for migrating from the mother country to South Africa, stories of pain and suffering, of solidarity and heroism, of narrow escapes, of rape, of nasty experiences with corrupt and exploitative border officials, of attempts at avoiding such officials and

2 americamagazine.org/issue/763/article/theology-migration 
of course endless stories of hostility and xenophobia. These stories are a rich source of field research and in terms of the logic of the praxis cycle used in the article, form an indispensable part of a theology of migration.

\section{A liturgical-communal theology}

A rather creative and exciting development in their journey with migration between Mexican and American Christians, is the celebration of the Eucharist or Holy Communion right on the border between their respective countries on an annual basis. It is not surprising that the event is mainly A Catholic occasion since in Catholic circles, in the church and in theology, there seems to be a much greater sense of the symbolic and the ritualistic than in the Reformed tradition, for example, with its accentuation of the "word". More often than not the symbolic and the ritualistic speak clearer than all the preaching we may be able to do. Annually a "civilization of love” (Groody 2011:34) is constituted near El Paso, Texas, on the border between Mexico and the United States, close to the area where many immigrants lose their lives. Coming together for the eucharist are bishops, priests and lay people despite being divided by a sixteen-foot high iron fence.

\section{Liturgy of the eucharist}

In a review of Promised Land, A Perilous Journey, Sweeden (2008) points to how Groody (2008:304-305) creates parallels between the migrant's journey and the structural core of the liturgy of the eucharist in Luke's gospel. In reference to four verbs, "he took the bread", "he said the blessing", "he broke the bread", and with reference to the cup, "he gave it to his disciples", Groody draws parallels to the migrant's need for bread, the testimony of faith and thankfulness amidst sadness, suffering and pain, the migrant being broken to provide bread for the family and the migrant pouring out the life for the good of others. This is deep theology and opens up creatively new avenues for the interpretation of rituals and ceremonies from the perspective of migration. In South Africa the funeral ritual is quite important in black communities. Contrary to some interpretations the way some South Africans go about funerals has got very little to do with an obsession with or a fear of death, but rather a celebration of life. Amidst the huge challenge of coming to grips with dying as part and parcel of human identity, the solidarity experienced and the celebration around a consolation meal at funerals feed into a deep understanding of life. The very ritual of helping a bereaved family and the deceased to "cross over" with the distinct metaphor of "crossing over the river" is a rather fruitful metaphor for theological reflection on migration. There are other symbols and rituals still like baptism, tombstone unveilings and wedding ceremonies with great potential for new interpretations from the perspective of migration. On baptism, just very briefly, there is a very interesting connect in 1 
Corinthians 10 between the exodus and baptism with specific reference to the journey through the desert in which God's wonderful providence is contrasted with the idolatry of his people. In a subversion of the text from the perspective of migration, theological reflection around how new idols in the mode of consumerism and greed, cause migration and how it is in the desert that migrants learn to eat from God's own hand, could make for some creative reading.

\section{An intercultural and interreligious theology}

That a theology of migration would inter alia be an intercultural and interreligious theology feeds into the very basic reality that human migration, if anything, is the encounter between cultures and faiths or religions. In South Africa migration has become the meeting place between cultures from different African countries like Somalia and as far afield as Pakistan which account mainly for the encounter between Muslims and Christians as well as adherents to the ATR.

A note needs to be made on why the concepts "intercultural" and "interreligious" are appropriate in the context of this paper and not "cross-cultural" and "cross-religious". By predicating cultural and religious on "inter", some consistency is created between "konvivenz" as living together rather than a tangential encounter between cultures and religions. This poses a major challenge to South Africans in terms of opening up radically to strangers and rendering themselves vulnerable to change and transformation. In specific reference to the church, Bevans (2008) feeds into the hospitality challenge and pilgrimage identity of the church. He suggests that the transformation of the church occurs when migrants are viewed not as "strangers", but as "gifts" who participate in the church, shaping and contributing to the identity and life of the church.

\section{"Konvivenz"}

It is indeed interesting to note that one of the strong theories on the origin of "konvivenz" or "convivencia”, a Spanish concept which means living together, cohabitation or coexistence, is its origination in Spain in the early eighth century with the Umayyad conquest of Hispania. For centuries after the conquest, Muslims, Christians and Jews lived together in relative peace, much as the Christian re-conquest was ongoing during this time. There seemed to have been a discourse and interplay between cultural ideas as well as a significant level of religious tolerance. What is documented also is that the culture of Al-Andalus, as the area was known, was a "composite hybrid culture", consisting of a "combination of various artistic elements from Catholic, Classical Roman and Byzantine artistic traditions". ${ }^{3}$ Indeed, "The hybrid works that were produced under, and resulted from Muslim

3 http://en.wikipedia.org/wiki/Social_and_cultural_exchange_in_Al-Andalus 
rule of Al-Andalus, resulted in what has become known as the Golden age of Jewish culture in Spain and laid the foundation for the European Renaissance and Scientific Revolution”. ${ }^{4}$

In the encounter between migrants and locals, the challenge particularly on the side of the locals will be to enter into a relationship with migrants that clearly demonstrate the willingness to not only welcome the brother or sister from elsewhere in the region, but to live together with him or her. In the story on Al-Andalus where Muslims, Christians and Jews lived peacefully together, the idea was not to have an entirely new culture emerge, but to learn to live with hybridity. In theological terms the challenge is to recognise Christ in the migrant. Bevans states this in metaphorical terms by speaking of the "Border Christ" and the "Migrant Christ". In his intercultural theological perspective on migration, Rivera-Pagán (2012) contends that one of the concerns or fears with Americans in the encounter with "resident foreigners", is the consequence on national identity. He suggests that instead of perceiving of identity as "an already historically fixed essence”, it should rather be seen as historically constructed and constituted "by exchanges with peoples bearing different cultural heritages”.

\section{Strategic planning}

The fourth step of the cycle does not refer to just any kind of planning, but rather the type of strategic planning that is informed by the aforegoing steps of insertion, context analysis and theological reflection as well as an improvement in the action to be taken. In the encounter between migrants from other SADC countries and South Africans the matter is about dealing with xenophobia and inculcating radically new relationships.

\section{Back to Sundermeier's "konvivenz"}

For purposes of the planning to be suggested in the paper the concept of "konvivenz" as understood by Sundermeier is called into service. As complex as the issue may be, the use of Sundermeier's triad of learning, caring and celebrating communities, suggests that these are the areas where action is required. If Sundermeier is interpreted correctly, the triad goes beyond a mere encounter between migrants and locals and is much more than good communication between migrants and South Africans. To be true, even the offerings on a theology of hospitality are to be scrutinised on whether they do not suggest a kind of openness, friendliness, tolerance and a particular measure of sharing with migrants or whether they propose something deeper. There are of course quite a number of such theologies of

4 http://en.wikipedia.org/wiki/Social_and_cultural_exchange_in_Al-Andalus 
hospitality that have emerged the past few years, but it is entirely beyond the scope of the paper even to start engaging them critically.

\section{Learning communities}

His proficiency in English will tell you that Charles (2011, 2012) has had a solid education in Zimbabwe. In engaging him on why he does not try to find a more suitable job in South Africa, he is quick to explain that by diversifying and by being willing to do just any job South Africans may care to offer him, he is able to earn quite some income. The jobs he does on a daily basis ranges from small tasks as a handyman, car washing, painting and gardening. This has enabled him to buy a buggy in South Africa for fishing in Zimbabwe. When he disappeared for months in 2012, some were wondering what happened to Charles only to learn with his return from Zimbabwe that he went back there to get his fishing business going. The deal with the people in Zimbabwe who have joined him in his fishing is that they are remunerated in kind, not cash. For example, if the catch amounts to thirty kilograms of fish, it will be shared amongst them for selling on the market or just locally.

In South Africa, unfortunately, with the introduction of the ideology of delivery, quietly, a type of "daddy state" has been created in the country. Much as any government or state has the responsibility to deliver to its citizens in a number of distinct areas like water and sanitation, infrastructure, safety and security, education and health care, in South Africa delivery has become a very potent weapon in the hands of the powerful even when such delivery is lacking.

By creating and inculcating learning communities the church can bring the simple story of the Zimbabwean into discourse with the notion of the "daddy state" where citizens expect the government to literally do everything for them. The story of Charles is an important learning curve since it reveals that there are creative ways of earning a livelihood, however difficult these may sometimes be.

\section{Deep learning}

The suggestion here is, however, not that the learning is to be reduced to some measure of economic activity. There is a rich variety of areas where learning can take place: culture, faith or spirituality, tolerance, human rights and a host of very basic human issues. Deep learning can only take place if indeed the interface between locals and Zimbabweans, for example, transcends the need for encounter and good communication. It is only in some form of community or "konvivenz", i.e. living together that such learning is possible.

The underlying assumption in starting this portion with the story of Charles, is that the learning in the kind of community envisaged and 
emanating from the encounter between migrants and South Africans, is by definition a learning through narrative.

\section{Caring communities}

The caring aspect of "konvivenz" feeds strongly into Matthew 25:35 which reads: "I was a stranger and you invited (NIV)/welcomed (SV) me in". Once again, "konvivenz" in Sundermeier's interpretation is more than occasionally inviting strangers for a meal, but the construction of sustainable caring communities. In the South African townships there are wonderful remnants of "ubuntu" to be found. It is the kind of spirit which says that one's own identity is only understood through another's identity: "I am because we are and we are because I am" as explicated in a book titled Townships and the Spirit of Ubuntu (Telschow 2003:2). Township people still know what it means to care for one another and to be in solidarity with one another amidst the challenges and hardships of life. The stories told in the book alluded to and the wonderful photographic material reveal an enacted "konvivenz" in terms of how people live together and support one another. The outbreak of xenophobia in May 2008 should in a sense not be blamed on people who have to compete for very scarce goods against migrants from countries in the SADC region and further afield, but on the systems and mechanisms that have produced these circumstances. The prevailing spirit of "ubuntu" opens a window of hope in the encounter between South Africans and migrants which goes way beyond mere tolerance and decency to the establishment of communities where deep caring takes place.

\section{Celebrating communities}

The diversity in cultural, religious and ecclesiastical background might in the construction of small communities between South Africans and migrants from countries in the SADC region, militate against the celebration of baptism and the Holy Communion in the formal ecclesial sense of the word. A very creative source of celebration could be the agape meal enjoyed by early Christians. There are numerous other sources of celebration which could be called into service for creating a greater sense of community between locals and migrants. In the context of internal migration, i.e. unfortunate homeless migrants in the city of Pretoria-Tshwane, the Department of Christian Spirituality, Church History and Missiology at the University of South Africa (Unisa), is involved in a project named "Meal of Peace: 100 homeless people project". This is a community engagement initiative of the unit aimed at a diaconal ministry and research into homelessness. Annually there is a "meal of peace" which is perhaps an example of the kind of celebration that is feasible with migrants (Mangayi 2013). 


\section{Conclusion}

The purpose of the paper was to start drawing some contours of a theology of migration for the SADC region by using the praxis cycle. The cycle is re-emerging as a potent methodological instrument for constructing something like a context-based theology of migration. In further research into migration in the SADC region, the challenge shall be to allow insertion and context analysis more consistently to inform the theological reflection and strategic planning. In broad terms the paper is suggesting that any theology of migration which takes seriously the complex of issues around migration, will have to say something about God-language from the perspective of migration, narrative, liturgy in community and intercultural and interreligious dimensions in a theology of migration. This is the bare minimum.

\section{References}

Askevold, T. 2007. We are all sons and daughters of a wandering Aramean. StudentWorld 07, 251: 45-50.

Bevans, S. 2008. Mission among Migrants, Mission of Migrants: Mission of the Church in A Promised Land, A Perilous Journey. Theological Perspectives on Migration edited by Groody DG and Campese, G. Notre Dame: University of Notre Dame Press, 89-106.

Confession of Belhar. 1986.Bellville: LUS Drukkery.

Groody, DG. 2008. Fruit of the Vine and Work of Human Hands: Immigration and the Eucharist in A Promised Land, A Perilous Journey. Theological Perspectives on Migration edited by Groody, DG. and Campese, G. Notre Dame: University of Notre Dame Press, 299-315.

Groody, DG. 2009. Crossing the Divide: Foundations of a Theology of Migration and Refugees. Theological Studies 70: 638-667

Groody, DG. 2011. A Theology of Migration. A new method for understanding a God on the move in Americamagazine, February 2011 posted at http://americamagazine.org/issue/763/article/theoloy-migration and accessed on 2013/06/13.

Groody, DG. 2011. Christology at the U.S./Mexico Border: An Eschatological View in Jesus of Galilee: contextual christology for the 21st century edited by Lasalle-Klein, R and Alonso P. Maryknoll, New York: Orbis Books, 249-261.

Groody, DG. 2005. Undocumented migration and religious experience: a theological interpretation of the Mexican-American border in Encountering transcendence: contributions to a theology of Christian religious experience edited by Boeve L, Geybels, H and Van den Bosche, S. Leuven; Dudley, MA: Peeters, 359-374.

Holland, J and Henriot, PJ. 1983. Social analysis. Linking faith and justice. Maryknoll, New York: Orbis Books. 
Interviews with "Charles" on an informal, unstructured basis were conducted over a period of time during 2011 and 2012

Landman, C. 2012. Participating in the Joint Conference of academic societies in Religion and Theology held at the Pietermaritzburg campus of the University of Kwazulu-Natal from 18-22 June 2012.

Loza León, JL. 2007. Renewing Theology of Migrations in StudentWorld07 251: 23-30.

Mangayi, CL. 2012. Participating in the Joint Conference of academic societies in Religion and Theology held at the Pietermaritzburg campus of the University of Kwazulu-Natal from 18-22 June 2012.

Mangayi, CL. 2013. Draft document titled Working with the homeless for peace and justice in Pretoria, A Community Engagement initiative of the Department of Christian Spirituality, Church History and Missiology at Unisa.

New International Version of the Bible

Rivera-Pagán, L. 2012. Xenophilia or Xenophobia: Towards a Theology of Migration in Online magazine of theology and culture at http://www.lupaprotestante.com/lp/english/xenophilia-or-xenophobia-towards-a-t heology/

Saman, B. 2007. Jesus Christ: Asylum Seeker, Refugee and a Migrant in StudentWorld 07 251: 51-60.

Schachter, JP. 2009. Data Assessment of Labour Migration Statistics in the SADC Region: South Africa, Zambia, Zimbabwe. International Organization for Migration.

Sundermeier, Th. 1995. Konvivenz und Differenz: Studien zu einer verstehenden Missionswissenschaft: Anlässlich des 60. Geburtstages von Theo Sundermeier. Erlangen: Verlag der Evangelisches-Lutherischen Mission.

Sweeden, N. B, 2008. A review of A Promised Land, A Perilous Journey. Theological Perspectives on Migration edited by Groody, DG and Campese, G. Notre Dame: University of Notre Dame Press.

Telschow, M. 2003. Townships and the Spirit of Ubuntu. Cape Town: Clifton Publications.

Tshaka, R. 2010. Do our Theological Methodologies help us to deal with situations of violence in black communities? Specifically Afrophobia? Journal of Theology for Southern Africa 138: 91-111.

Williams, V. 2002. An overview of migration in the SADC region. Presented at SAMP/LHR/HSRC Workshop on Regional Integration, Poverty and South Africa's Proposed Migration Policy, Pretoria. 